\title{
ACCEPTABILITY AND USE OF INNOVATIVE BAMBOO PRODUCTS FOR THE CONSTRUCTION OF RESIDENTIAL BUILDINGS IN NIGERIA
}

\author{
John Ameh $^{1 *}$, Aliu Soyingbe ${ }^{1}$, Olukayode Oyediran ${ }^{2}$ \\ ${ }^{1}$ Department of Building, University of Lagos, 100213 Nigeria \\ ${ }^{2}$ Department of Quantity Surveying, University of Lagos, 100213 Nigeria
}

(Received: November 2018 / Revised: December 2018 / Accepted: June 2019)

\begin{abstract}
The high cost and environmental and health hazards attributed to conventional building materials, coupled with the adverse effect of massive exploitation of forest resources for construction purposes, have necessitated the search for alternative construction materials that are eco-friendly, sustainable, economical and socially acceptable. This study aims to explore the acceptability and use of innovative bamboo products for residential building construction in Nigeria. One hundred and fifty-two survey questionnaires were distributed to built environment professionals within the Lagos region using the convenience sampling technique. The results show a likely disposition to the use of innovative bamboo products for building construction, except for roof beams and trusses, wall beams and columns, and composite roofing sheets. Major barriers to the acceptability and use of bamboo for construction include lack of knowledge about bamboo connections and detailing; the absence of governmental policy on bamboo as an alternative construction material; the absence of design standards for bamboo products; and poor public perception of the use of bamboo in building construction. The value of this study is that it provides an excellent platform for further research on the optimization of bamboo for construction, which will boost economic activities, reduce capital flight for the importation of machinery and the constituents of conventional building materials, and enhance the country's GDP.
\end{abstract}

Keywords: Bamboo; Building materials; Eco-friendly; Nigeria; Sustainable material

\section{INTRODUCTION}

There are indications from global trends that the world is experiencing a housing crisis, but that this is more severe in developing countries. Data from the National Bureau of Statistics (NBS, 2012) and the World Bank (2016) agree that Nigeria has an estimated housing deficit of over 17 million units. It has been reported that Lagos, the commercial nerve center, and Abuja, the capital city, account for $15 \%$ and $10 \%$ respectively of the total housing deficit (Sanni, 2017). With the urban population growth rate at $4.39 \%$ (World Bank, 2016), housing for both rental and purchase will continue to be in high demand. Jagboro and Owoeye (2004) attribute around $60 \%$ of the overall cost of building construction to building materials; prices of these in Nigeria are unstable due to inflation and are rising annually (Oke \& Akanni, 2012).

Modern construction mostly uses non-renewable and non-green materials such as cement and steel, which have consequences for the environment and ecosystem. Products made from nongreen materials require a substantial amount of energy for processing and transportation, which

${ }^{*}$ Corresponding author's email: oameh@unilag.edu.ng, Tel. +234-8023323711
Permalink/DOI: https://doi.org/10.14716/ijtech.v10i4.2574 
contribute to the greenhouse effect. In addition, high levels of foreign exchange are required for the importation of heavy machinery and constituent materials for their production. The interiors of buildings made from non-green materials require additional ventilation, which is often provided artificially, thus exerting more pressure on the inefficient and inadequate electric power supply in developing economies such as Nigeria. An alternative conventional construction material that is eco-friendly, sustainable and economical is wood. However, the demand for wood and wood products continues to increase in proportion to population levels. The implication of increasing demand for wood as a forest resource is deforestation, as the rate of demand for such forest resource is higher than the rate of replenishment. It is common knowledge that trees take decades to mature, thus massive exploitation of forest resources for construction and other uses may lead to their depletion, with the attendant impact on sustainability and ultimately climate change. Bonsi (2009) observes that the survival of the wood industry requires a corresponding supply of adequate wood raw material. However, Ayres (2001) found that the primary resource base can no longer provide an adequate supply of wood to industry. Therefore, Upton and Attah (2003), Donkor et al. (2005), and Tomaselli (2007), advocate the adoption of lesser-used or plantation-grown species in order to stabilize the disequilibrium in supply.

The environmental and health hazards attributed to non-green conventional building materials, coupled with the adverse effect of massive exploitation of forest resource for construction purpose, have necessitated the search for alternative construction materials that are eco-friendly, sustainable, economical and socially acceptable (fashionable). Bamboo is one of the strongest and most versatile eco-friendly building materials in the world (Shah et al., 2012). Bamboos are giant grasses belonging to the family Gramineae, a sub-family of Bambusoideare (Effah et al., 2014). Available records indicate that there are between 1,200-1,500 species of bamboo found in 70 genera, of which Bambusa Vulgaris is the dominant species in Nigeria (Gyansah \& Kwofie, 2011).

Several investigations into the use of bamboo as a suitable material for construction have been made (Mbuge, 2000; Awalluddin et al., 2017). It has been successfully used as structural columns and trusses in the Philippines (Richard et al., 2017), while a study by Sharma et al. (2017) established that laminated bamboo was comparable to conventional timber and timber- based products in terms of structural properties. Despite extensive research reports on the suitability of bamboo for construction, there is no policy on its use for construction in Nigeria. The lack of modern technology input into the processing of bamboo for housing accounts for its low acceptability and utilization as a building material in Nigeria. Because of the relative lack of exploitation of bamboo for construction in most African countries, in comparison to its use in China, India and Latin America countries, for example, Opoku et al. (2016) examined the barriers to the use of bamboo for construction in Ghana. The limitation of their study is that many of the respondents would have responded from the viewpoint of traditional uses of bamboo for construction. Innovative bamboo products (also called engineered bamboo) are revolutionary new products made from bamboo culms, with improved strength characteristics and durability (Sharma et al., 2015). They are used as floor tiles, wall partitions, ceilings and roofs.

The International Network for Bamboo and Rattan (INBAR) (2011) observes that barriers exist to the mainstreaming of bamboo in construction. Some of these include policy support and integration with local construction materials; preparation of bamboo construction product standards and codes; and supply of bamboo on an industrial scale for construction purposes. These barriers are fundamental. They require analysis of the fundamental issues in the feasibility and acceptability of the adoption of innovative or engineered bamboo products in construction. This is important in the context of the reluctance to adopt certain innovative alternative construction products and processes in countries that are accustomed to either foreign and/or conventional construction materials. For these reasons, this study is aimed at exploring the 
acceptability and use of innovative bamboo products for residential building construction in a developing country, namely Nigeria, with a view to providing a benchmark stakeholder mindset that could drive both the technology and adoption of this promising alternative construction material.

The study therefore intends to achieve the above aim by examining the current use of bamboo for construction purposes in developing economies such as Nigeria; by examining the acceptability of bamboo products as an alternative to wood for construction; and by identifying the factors which affect its acceptability and use in building construction.

\section{METHODS}

The research design adopted was a cross-sectional survey. This was conducted among built environment professionals (for example, architects, builders, civil engineers and quantity surveyors), who operated in two contagious geographical environments (Lagos and Ogun States, Nigeria), where high volume and active construction activities are ongoing. At this stage of the enquiry, and coupled with the non-existence of a database from which a scientifically determined sampling frame could be adopted, a convenience sampling frame was used. Data were sought from 250 potential respondents, with a $61 \%$ (152 appropriate responses) response rate attained.

The instrument for data collection comprised a three-section questionnaire. The first section sought to obtain experience-based information on the current use of bamboo products for construction, measured on four-point Likert type scale. The scale comprised "participated in using it", rated as 4; "aware it has been used", rated as 3; "seen or know where it was used", rated as 2 and "never used nor seen where it was used", rated as 1 . The second section examined the acceptability of the identified innovative (engineered) bamboo products, also using a four-point Likert type scale, which ranged from "most likely", rated as 3; "likely", rated as 2; "not likely", rated as 1 and "never", rated as 0 . The third section identified the perceived barriers to the acceptability and use of bamboo products for building construction, in this case using a five-point Likert type scale, which comprised "strongly agree", rated as 5; "agree", rated as 4; "disagree", rated as 3; "strongly disagree", rated as 2; and "indifferent", rated as 1.

The data obtained from the survey were subjected to measures of central tendency statistics. The summated rating scale employed the weighted mean to explain the behavior or pattern of the construct under investigation.

\section{RESULTS AND DISCUSSION}

\subsection{Perception of Professionals on the Future of Bamboo as a Building Material}

The views of the built environment professionals (as shown in Figure 1) on the acceptability of bamboo by stakeholders in the building industry as an alternative building material were quite revealing. The consensus was that bamboo is a material for low cost housing construction, being considered as a building material for the poor. The respondents also agreed that clients and commercial property developers will embrace the use of innovative (engineered) bamboo products for building construction. Considering the segment of the housing market that has an acute housing deficit, it is apparent that bamboo may be one of the products that can be used for middle income and low-income housing solutions. It could also be an option for rural and semiurban settings. It is therefore unlikely that the affluent will embrace houses built with bamboo or bamboo products. Notwithstanding this, the poor and middle class are in the majority in any country, meaning investment in bamboo is guaranteed to be highly rewarding. 


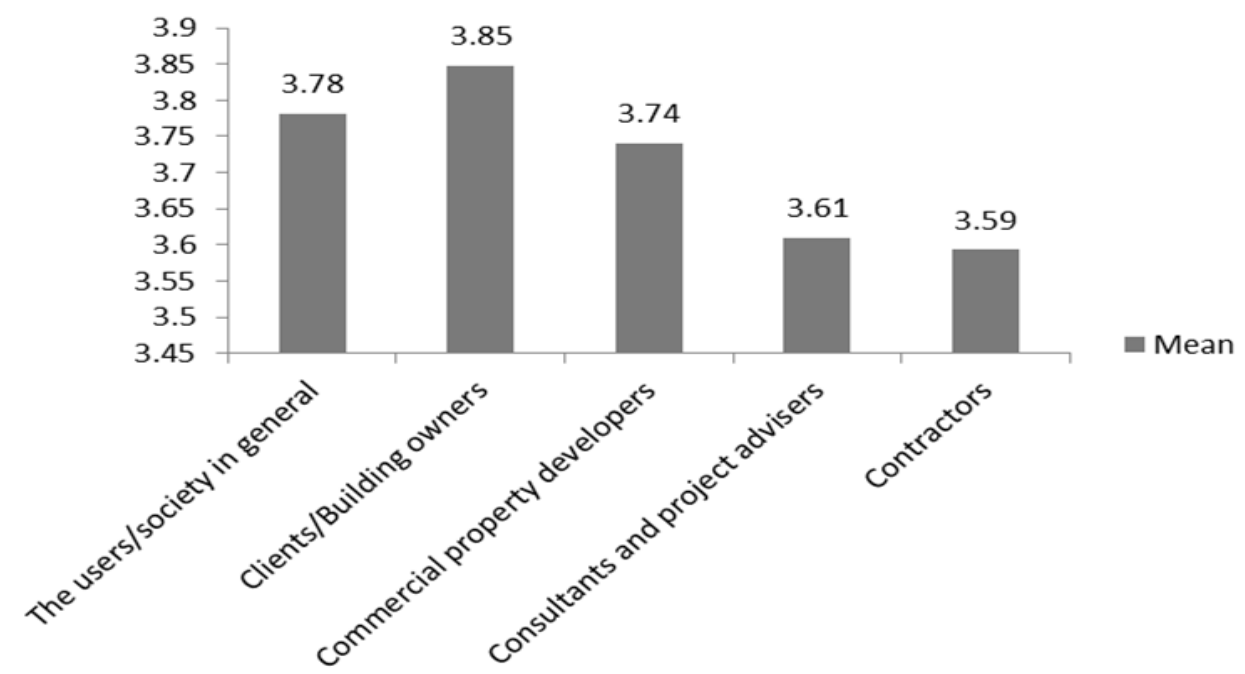

Figure 1 Views on the uncertainty of bamboo as an acceptable building material

\subsection{Experience and Views on Use of Bamboo for Construction}

Table 1 shows a summary of the respondents' experience and views on past and present use of bamboo for building in Nigeria. The aim was to examine the extent of knowledge on bamboo utilization in building construction. The results show an average level of awareness and experience in the structural use of bamboo, particularly for roof and wall construction. Roof structures and walls, as structural members in house construction, top the predominant area of bamboo application. Another major area of the application of bamboo in construction is as temporary support for formwork and scaffolding in buildings, as confirmed by the respondents. The results further indicate that the use of bamboo for finishes is uncommon; Table 1 shows this in terms of both awareness and actual use, as more than half the respondents had neither used nor seen where it was used as a finish for wardrobe linings, doors and dividers, or for kitchen cabinets. Similarly, the results reveal that the use of bamboo for ornamental or decorative purposes is rare, with only a few respondents claiming to be aware of its use for such purposes.

The results of this study confirm the findings of Onuora et al. (2014) that the use of bamboo for industrial application in Nigeria is in its infancy; in the building industry, it is still not exploited to the full. The use of bamboo as a housing material is well established in rural areas of many tropical countries, where it is grown in abundance. The abrasive properties of Bambusa vulgaris have been found to be 30 percent superior to those of Kempas (Koompasia melaccensis), a common flooring material in Malaysia, and about five times greater than rubber wood, therefore being suitable for flooring purposes under medium traffic conditions (Mohmod et al., 1988). The suitability of bamboo as a substitute for steel in normal and lightweight concrete has been investigated, with promising results. Xiao et al. (2010) successfully designed and constructed a 10-meter single lane roadway bridge using large size laminated bamboo girders, or GluBam girders in China. Vogtländer et al. (2010) also reported on ply-bamboo and strand woven bamboo from the Phyllostachys Pubescens species. In fact, in China bamboo is a valuable material, with a multi-billion-dollar bamboo industry, and it has been developed as an exceptionally valuable and often superior substitute to timber. 
Table 1 Experience and/or views on the use of bamboo for building in Nigeria

\begin{tabular}{|c|c|c|c|c|c|}
\hline \multirow[b]{2}{*}{ Possible use } & \multicolumn{5}{|c|}{ Percentage } \\
\hline & $\begin{array}{c}\text { Participated } \\
\text { in using it } \\
4\end{array}$ & $\begin{array}{c}\text { Aware it } \\
\text { has been } \\
\text { used } \\
3\end{array}$ & $\begin{array}{c}\text { Seen or know } \\
\text { where it was } \\
\text { used } \\
2\end{array}$ & $\begin{array}{c}\text { Never used } \\
\text { nor seen it } \\
\text { so used } \\
1\end{array}$ & Mean \\
\hline \multicolumn{6}{|c|}{ Structural use of bamboo } \\
\hline $\begin{array}{l}\text { Reinforcement in mud (adobe) } \\
\text { houses }\end{array}$ & 9.4 & 41.6 & 18.1 & 30.9 & 2.30 \\
\hline Reinforcement in concrete elements & 14.6 & 26.4 & 9.0 & 50.0 & 2.06 \\
\hline Columns or pillars in buildings & 16.4 & 34.2 & 15.1 & 34.2 & 2.33 \\
\hline $\begin{array}{l}\text { Roof structures (rafters, struts, } \\
\text { purlins, etc.) }\end{array}$ & 18.7 & 42.7 & 22.7 & 16.0 & 2.64 \\
\hline Walls for houses & 12.6 & 37.7 & 34.4 & 15.2 & 2.48 \\
\hline Structural floors & 11.2 & 35.7 & 20.3 & 32.9 & 2.28 \\
\hline $\begin{array}{l}\text { Agricultural houses (farmhouse } \\
\text { storage) }\end{array}$ & 19.2 & 43.7 & 28.5 & 8.6 & 2.74 \\
\hline \multicolumn{6}{|c|}{ Temporary use of bamboo } \\
\hline Fences & 33.1 & 37.1 & 23.4 & 6.5 & 2.97 \\
\hline $\begin{array}{l}\text { Props to support formwork to lintels, } \\
\text { beams and slabs, etc. }\end{array}$ & 61.1 & 20.1 & 17.4 & 1.3 & 3.41 \\
\hline $\begin{array}{l}\text { Temporary support as scaffolding for } \\
\text { low rise building construction }\end{array}$ & 63.3 & 16.0 & 16.0 & 2.7 & 3.44 \\
\hline \multicolumn{6}{|c|}{ Use of bamboo for finishes } \\
\hline $\begin{array}{l}\text { Internal wall panels for the } \\
\text { partitioning of rooms and spaces }\end{array}$ & 11.2 & 34.9 & 21.1 & 32.9 & 2.24 \\
\hline Ceiling panels & 10.9 & 37.4 & 22.4 & 29.3 & 2.30 \\
\hline Parquet flooring & 9.7 & 39.3 & 16.6 & 34.5 & 2.24 \\
\hline Window leaves/panels & 10.2 & 29.3 & 23.8 & 36.7 & 2.13 \\
\hline Door leaves/panels & 12.3 & 27.4 & 24.7 & 35.6 & 2.16 \\
\hline Wardrobe lining, doors and dividers & 8.2 & 21.2 & 19.2 & 51.4 & 1.86 \\
\hline Kitchen cabinets & 8.8 & 21.1 & 18.4 & 51.7 & 1.87 \\
\hline Storage shelves and dividers & 10.9 & 27.9 & 21.8 & 39.5 & 2.10 \\
\hline \multicolumn{6}{|c|}{ Ornamental or decorative use of bamboo } \\
\hline Dining tables & 10.9 & 35.4 & 19.0 & 34.7 & 2.22 \\
\hline House chairs & 14.8 & 42.3 & 28.2 & 14.8 & 2.57 \\
\hline Garden/recreational tables and chairs & 18.4 & 43.1 & 27.6 & 10.5 & 2.70 \\
\hline
\end{tabular}

\subsection{Potential Acceptability of Bamboo Products if Available}

The results shown in Table 2 indicate that the respondents exhibited a likely disposition to use bamboo plywood, bamboo fiber board, or laminated bamboo for general purposes as a substitute for wood, as well as bamboo board for wall partitions, and bamboo strips for both ceiling and flooring. On the other hand, they indicated that they were unlikely to accept bamboo for use as roof beams and trusses, wall beams and columns or composite roofing sheets.

This disposition perhaps accounts for why the use of bamboo is not promoted by professionals in the built environment. If professionals, who should be familiar with the properties of bamboo (as a green building materials) are reluctant to promote its usage by specifying it as a substitute for certain components (e.g. wood and steel) or as a composite material, then the government and private developers will never tap into its potential. In South America, India and China, public facilities have been constructed with bamboo. Popular bamboo architectural works around the world are include the Floating Bamboo Courtyard Teahouse, which sits on a lake in Yangzhou, China; the Waterside Kontum Indochine Café in Vietnam, comprising top heavy bamboo columns; low cost housing in Vietnam; and a school made entirely from bamboo in Bali, Indonesia. A course on Building Materials is taught in the first two or three years of study in built 
environment disciplines in both polytechnics and universities in Nigeria. Advances in material studies place emphasis on eco-friendly and sustainable materials, so it is hypocritical to teach about green, renewable and sustainable development, particularly in the housing sector, while building infrastructure employs concrete, steel and the last remaining rainforest resources (timber). Prastyatama and Maurina (2017) also advocate that study of (architectural) materials should aim at evoking primordial human emotions to bridge the gap of disconnectedness with earthy materiality. Juwono (2017) advocates that the use of natural materials in traditional housing will preserve the environment.

Table 2 Potential acceptability of products made from bamboo

\begin{tabular}{lccc}
\hline \multicolumn{1}{c}{ Bamboo product } & $\mathrm{N}$ & Mean & $\begin{array}{c}\text { Standard } \\
\text { Deviation }\end{array}$ \\
\hline Bamboo ply board & 152 & 2.34 & 1.794 \\
\hline Bamboo fiber board & 151 & 2.19 & .787 \\
\hline $\begin{array}{l}\text { Laminated bamboo for general use as a } \\
\text { substitute for wood }\end{array}$ & 149 & 2.12 & .829 \\
\hline Bamboo boards for wall partitions & 149 & 2.12 & .779 \\
\hline Bamboo strips for ceilings & 152 & 2.09 & .856 \\
\hline Bamboo strips for flooring & 149 & 2.03 & .850 \\
\hline $\begin{array}{l}\text { Treated bamboo culms for roof beams and } \\
\text { trusses }\end{array}$ & 151 & 1.83 & .893 \\
\hline $\begin{array}{l}\text { Treated bamboo culms for wall beams and } \\
\text { columns }\end{array}$ & 152 & 1.76 & .882 \\
\hline Bamboo fiber composite roofing sheets & 149 & 1.70 & .842 \\
\hline
\end{tabular}

\subsection{Barriers to the Acceptability and Use of Bamboo for Building Construction}

Table 3 present the results of the respondents' perception of factors that serves as barriers to the acceptability and use of products made from bamboo for building construction. The main factors are lack of knowledge about bamboo interconnectivity and detailing; the absence of government policy on bamboo as an alternative construction material; the absence of design standards for bamboo products; poor public perception of the use of bamboo in the construction of buildings; and reluctance to specify bamboo by design professionals. Contrary to the expectations of the study, factors such as the low resistance of bamboo to insect attack; difficulty in identifying appropriate species out of the over 100 available; and difficulty in working with bamboo (joint connections) were considered less significant barriers to its acceptability and use.

In a related study in Ghana, Opoku et al. (2016) reported the perceptions of building contractors and architects regarding factors inhibiting the use of bamboo for building construction. From their results, building contractors perceived failure on the part of architects to specify bamboo for building projects; inadequate bamboo processing companies; insufficient cooperation from the government; the problems of social acceptability and limited knowledge of bamboo; and lack of expertise in using it to be dominant factors. Architects, on the other hand, cited lack of knowledge of bamboo detailing; limited knowledge of bamboo and lack of expertise in using it; inadequate bamboo processing companies; lack of durability when untreated; and competition from other building materials as the key factors affecting use of the material. With appropriate government policies on the use of bamboo or bamboo products for public building construction, and an effective bamboo product processing industry, the social stigma about bamboo being a poor man's timber will be eradicated. 
Table 3 Perceived barriers to the acceptability and use of bamboo for building construction

\begin{tabular}{lccc}
\hline \multicolumn{1}{c}{ Factor } & $\mathrm{N}$ & Mean & $\begin{array}{c}\text { Standard } \\
\text { Deviation }\end{array}$ \\
\hline Lack of knowledge about bamboo interconnectivity and detailing & 148 & 4.18 & .865 \\
\hline No government policy on bamboo as an alternative construction material & 150 & 4.13 & 1.008 \\
\hline No design standards for bamboo products & 147 & 4.10 & .920 \\
\hline Public perception of the use of bamboo in building construction is poor & 152 & 4.09 & .856 \\
\hline Design professionals often fail to specify bamboo products & 149 & 4.03 & .933 \\
\hline No government support or appropriate legislation on the use of bamboo & 152 & 3.99 & 1.052 \\
\hline No industry for processing bamboo for construction & 150 & 3.99 & 1.099 \\
\hline $\begin{array}{l}\text { Construction industry professionals are not well informed about the } \\
\text { properties of bamboo }\end{array}$ & 153 & 3.92 & .885 \\
\hline Bamboo as a sustainable material is not included in the school curriculum & 150 & 3.88 & 1.074 \\
\hline Treated bamboo is not available for the construction of buildings & 151 & 3.85 \\
\hline No expertise in bamboo construction & 150 & 3.85 & 1.035 \\
\hline Bamboo products are highly susceptible to fire & 148 & 3.83 & 1.091 \\
\hline $\begin{array}{l}\text { High social stigmatization of the use of bamboo for the construction of } \\
\text { buildings (it is categorized as a construction material for the poor) }\end{array}$ & 150 & 3.82 & 1.037 \\
\hline Bamboo products have low resistance to insect attack & & 150 & 3.59 \\
\hline $\begin{array}{l}\text { Construction industry professionals face challenges in identifying } \\
\text { appropriate species out of the over 100 }\end{array}$ & 1.171 \\
\hline Bamboo culms are irregular in shape and difficult to work with & 3.50 & 1.293 \\
\hline
\end{tabular}

\section{CONCLUSION}

The purpose of the study was to explore the acceptability and use of innovative products made from bamboo for building construction in Nigeria, as a precursor of further research on the optimization of bamboo for construction. Survey questionnaires were administered to professionals in the built environment in the Lagos region. The results show an average level of awareness of and experience in the application of bamboo as structural members, particularly for roof and wall construction. A major area of application of bamboo is as temporary supports for formwork and scaffoldings. The results further indicate that the use of bamboo for finishes is uncommon.

With regard to the acceptability of products made from bamboo, the results show a likely disposition to use bamboo plywood, bamboo fiber board, laminated bamboo for general use as a substitute for wood, bamboo board for wall partitions, and bamboo strips for both ceilings and flooring. On the other hand, the respondents indicated that they were unlikely to accept bamboo for use as roof beams and trusses, wall beams and columns or composite roofing sheets.

Lack of knowledge about bamboo connections and detailing; absence of government policy on bamboo as an alternative construction material; absence of design standards for bamboo products; poor public perception of the use of bamboo in building construction; and reluctance to specify bamboo by design professionals are the barriers to the acceptability and use of bamboo for construction.

Future research should focus on the optimization of bamboo products that professionals perceive will attract patronage from stakeholders in the building industry, as well as addressing issues that act as barriers to the acceptability of bamboo products for building construction.

The practical implications of optimizing bamboo for the construction of buildings are that it would boost economic activities by creating multiple streams of employment for bamboo farmers, and for other citizens through the bamboo product value chain, leading to increased earning capacity and improved welfare of economically weaker sections of society. It would also 
discourage the importation of wooden panels and floor components, thereby increasing the country's GDP. In addition, it would contribute to a safe environment through carbon monoxide sequestration, and rehabilitation of degraded forests and other wasteland through bamboo plantation.

One limitation of this investigation is that it uses the convenience, rather than a probabilistic, sampling technique. Furthermore, the respondents were professionals in the built environment, rather than a widely-dispersed sample of building owners. Future studies should target all stakeholders in the building industry using a stratified or cluster sampling technique.

\section{REFERENCES}

Awalluddin, D.K., Ariffin, M.A.M., Osman, M.H., Hussin, M.W., Ismail, M.A., Lee, H., Lim, N.H.A.S., 2017. Mechanical Properties of Different Bamboo Species. In: MATEC Web Conference 138(4)

Ayres, R.U., 2001. The Need for a New Growth Paradigm. In: The Economics of Nature and the Nature of Economics. Cleveland, C.J., Stern, D.I., Costanza, R. (Ed.), Edward Elgar Publishing, Northampton, MA, USA, pp. 111-133

Bonsi, R., 2009. Adoption of Bamboo in Ghana's Forest Products Industry: An Investigation of the Principal Exporters and Institutions. Ph.D Dissertation in wood and forest products submitted to Virginia Polytechnic Institute and State University

Donkor, B.N., Vlosky, R.P., Attah, A., 2005. Appraisal of Government Interventions for Diversification of Species Utilization in Forest Product Exports: Lessions from Ghana. Journal of the Institute of Wood Science, Volume 17(1), pp. 1-10

Effah, B., Boampong, E., Asibey, O., Pong, N.A., Nkrumah, A., 2014. Small and Medium Bamboo and Rattan Enterprises in Economic Empowerment in Kumasi: Perspective of Producers. International Journal of Social Economics, Volume 1(1), pp. 11-21

Gyansah, L., Kwofie, S., 2011. Investigation into the Performance of Bamboo using the Notched and the Un-notched Specimen. Research Journal of Applied Sciences, Engineering and Technology, Volume 3(4), pp. 245-251

International Network for Bamboo and Rattan (INBAR), 2011. Development and Promotion of Bamboo Housing Technology in East Africa. Report Final Technical Project Report, Uganda, Kenya, Ethiopia

Jagboro, G.O., Owoeye, C.O., 2004. A Model for Predicting the Prices of Building Materials using the Exchange Rate of Nigeria. The Malaysian Surveyor, Volume 5(6), pp. 9-14

Juwono, I., 2017. Enhanced Treatment of Reeds as Natural Materials for Use in Traditional Housing at Wae Rebo Village in Flores. International Journal of Technology, Volume 8(6), pp. 1117-1123

Mbuge, D.O., 2000. Mechanical Properties of Bamboo (Bambusa Vulgaris) Grown in Muguga, Kenya. Master's Thesis, Graduate Program, Agriculture Engineering, Faculty of Engineering, University of Nairobi, Kenya. Available Online at erepository.uonbi.ac.ke:8080/xmlui/bitstream/handle/11295/19715/ONYANGO_D.M_M.S C._2000... Accessed on November 2, 2018

Mohmod, A.L., Mustafa, M.T., Samad, M.R., Midon, S.M., 1988. Wear Resistance of Two Commercial Bamboo Species in Peninsula Malaysia and Their Suitability as a Flooring Material. In: Proceeding of the $3^{\text {rd }}$ International Bamboo Workshop. Bamboos Current Research. Cochin, India, pp. 223-230

National Bureau of Statistics (NBS), 2015. Nigerian Real Estate Sector. Report 2010-2012. Available Online at https://www.proshareng.com/report/Nigerian\%20Economy/Nigeria-sHousing-Deficit-Estimated-at-17-Million-as-at-August-2012---NBS-/7898 
Oke, A.E., Akanni, P.O., 2012. An Assessment of Trend in the Cost of Building Material. Nigeria Environmental Research Digest, Volume 8(2), pp. 103-116

Onuorah, E.O., Nnabuife, E.C., Nwabanne, J.T., 2014. Potential of Bambusa Vulgaris Growth in Southeast Nigeria for the Manufacture of Wood-cement Panels. Journal of Minerals and Materials Characterisation and Engineering, Volume 2, pp. 263-373

Opoku, D., Ayarkwa, J., Agyekum, K., 2016. Factors Inhibiting the use of Bamboo in Building Construction in Ghana: Perceptions of Construction Professionals. Material Sciences and Applications, Volume 7(2), pp. 83-88

Prastyatama, B., Maurina, A., 2017. Material Studies as the Possible Channel to Re-Connect Dwelling and Building. International Journal of Technology, Volume 8(6), pp. 1108-1116

Richard, M.J., Kassabian, P.E., Schulze-Ehring, H.S., 2017. Bamboo Active School: Structural Design and Material Testing. Proceedings of the Institution of Civil Engineers-Structures and Buildings, Volume 170(4), pp. 275-283

Sanni, R., 2017. Forward Step with Affordable Housing. Nigeria Real Estate News. Available Online at https://nigeriarealestatehub.com/affordable-housing-2.html/, Accessed on August, 2018

Shah, R.A., Pitroda, J., Bambhava, H.D., 2012. Bamboo: Eco-Friendly Building Material in Indian Context. International Journal of Scientific Research, Volume 2(3), pp. 129-133

Sharma, B., Bauer, H., Schickhofer, G., Ramage, M.H., 2017. Mechanical Characterisation of Structural Laminated Bamboo. In: Proceedings of the Institution of Civil EngineersStructures and Buildings, Volume 170(4), pp. 256-264

Sharma, B., Gatoo, B., Bock, M., Mulligan, H., Ramage, M.H., 2015. Engineered Bamboo: State of the Art. In: Proceedings of the Institution of Civil Engineers-Construction Materials, Volume 168(2), pp. 57-67

Tomaselli, I., 2007. The Allure of Plantations. ITTO Tropical Forest Update, Volume 17(1), pp. $10-13$

Upton, D., Attah, A., 2003. Commercial Timbers of Ghana: Potential for Lesser-Used Species. Commonwealth Secretariat, London, UK

Vogtländer, J., Van der Lugt, P., Brezet, H., 2010. The Sustainability of Bamboo Products for Local and Western European Applications: LCAs and Land-use. Journal of Cleaner Production, Volume 18(13), pp. 1260-1269

World Bank., 2016. Nigeria Urban Population Growth Annual Percent - Trading Economics. Available Online at https://tradingeconomics.com/nigeria/urban-population-growth-annualpercent-wb-data.html, Accessed on November 02, 2018

Xiao, Y., Zhou, Q., Shan, B., 2010. Design and Construction of Modern Bamboo Bridges. Journal of Bridge Engineering, Volume 15(5), pp. 533-541 